\title{
OF ADVOCATES, DRUNKS AND OTHER PLAYERS: PLAIN TALES FROM AUSTRALIA*
}

\author{
The Hon Michael Kirby $A C C M G^{* *}$
}

\section{OF ADVOCATES}

When I retired from judicial office after 34 years service (13 of them as a Justice of the High Court of Australia), I was richly rewarded for my labours by the practising Bar. Here in England, Inner Temple did me the honour of electing me a Bencher. I was proud to follow Peter Taylor to that office. In Australia, the Australian Bar Association, the Law Council of Australia and the governing body of my home Bar, the New South Wales Bar Association, conferred on me honorary life memberships. I say this not to boast but to illustrate the forgiving qualities of barristers for the assaults that judges inflict on them during service in the courts.

I inherited the post as President in the New South Wales Court of Appeal, the busiest full-time appellate court in Australia, from judges of high talent but sharp tongues who made appearing before them an often fearsome and stomach-churning experience. ${ }^{1}$ Like Lord Taylor of Gosforth, in whose honour this lecture is established, I came into the inner circle of the Bench and Bar from the outside. I could never take pleasure in the discomfitures of barristers, where such conduct could redound to the disadvantage of their clients' arguments. Yet in my case, there was a still recent reason why the Bar might have held a grudge against me.

Traditionally, by the common law, a barrister in England and Australia, was immune from a suit in negligence, brought by a client, in respect of the barrister's professional performance in court. So much had been upheld by

\footnotetext{
* Delivered at Inner Temple, London on March 222011 as the Peter Taylor Memorial Lecture in honour of the late Lord Taylor of Gosforth, Lord Chief Justice of England and Wales (1992-1997).

** Justice of the High Court of Australia (1996-2009); Honorary Bencher, Inner Temple; Honorary Fellow, Society of Legal Scholars. The author acknowledges the assistance of Michael Munk, University of Technology, Sydney, in assembling materials.

1 A J Brown "The 'Inevitable' Judge" in I Freckleton and H Selby (eds) Appealing to the Future - Michael Kirby and his Legacy (Sydney: Thomson Reuters, 2009) p 49 at pp 62 and 67 (hereafter "Appealing").
} 
the High Court of Australia in 1988 in its decision in Giannarelli $v$ Wraith. ${ }^{2}$ In 2005, the principle in that case was questioned when a client brought proceedings in the Supreme Court of Victoria against both his barrister and solicitor claiming that their conduct had been lacking in the exercise of reasonable skill, care and diligence, so as to render them each liable, in contract and tort, for monetary damages to the client.

The case, D'Orta-Ekenaike $v$ Victoria Legal Aid, ${ }^{3}$ took a very long time to present its important questions of legal authority, principle and policy to the nation's final court. Ryan D'Orta-Ekenaike had been charged in February 1996 with rape. In July of that year, following legal advice, he pleaded guilty. However, on arraignment, he changed his plea and stood trial in the County Court of Victoria. At that trial, his plea of guilty was led in evidence and the accused was found guilty by the jury and sentenced to three years' imprisonment. He applied to the Court of Appeal of Victoria for leave to appeal against his conviction. That Court held that the instructions given by the trial judge on the use that the jury could make of the guilty plea were inadequate. The conviction was quashed and a new trial was directed. At the second trial, the judge ruled that the guilty plea at committal was inadmissible in the circumstances. The jury found the accused not guilty and he was discharged.

It was then that Mr. D'Orta-Ekenaike brought his civil proceedings in the County Court of Victoria against Victoria Legal Aid (VLA), which had acted as his solicitor, and against the barrister who had appeared for him at the committal proceedings and in his first trial. The pleadings alleged negligence, it being contended that both the barrister and the briefing officer of VLA had negligently advised him that he did not have a defence to the charge of rape; that if he pleaded guilty at the committal he would receive a suspended sentence; and that, if he did not plead guilty there, he would be convicted and would receive a custodial sentence. This advice was said to have been given out of court, at a conference in chambers two days before the commencement of the committal hearing. The advice was repeated on the day the hearing began, resulting in the guilty plea. Neither the solicitor nor the barrister had warned the accused that, if he pleaded guilty and subsequently sought to reverse that plea, it could be relied on by the prosecutor in the trial as an admission of guilt. The client relied on strong evidence that he was exposed to undue pressure and influence designed to induce him to plead guilty.

Based on the legal principle of immunity from liability in respect of the allegations of negligence, invoked by the lawyers, the trial judge in the County Court (Judge Wodak) permanently stayed the civil damages proceedings. He held that both VLA and the barrister were immune from

2 (1988) 165 CLR 543.

3 [2005] HCA 12; (2005) 223 CLR 1; [2006] 1 LRC 168, AusHC. 
legal liability. On this occasion, the Court of Appeal of Victoria refused leave to appeal from the trial judge's decision. An application for special leave to appeal to the High Court of Australia was referred to be decided, as on the return of an appeal, by the Full Court of that Court. This is where I became acquainted in the travails of Mr. D'Orta-Ekenaike.

The majority of the High Court of Australia (Chief Justice Gleeson and Justices McHugh, Gummow, Hayne, Callinan and Heydon) rejected the appeal. They held that a legal practitioner, whether acting as an advocate or as a solicitor instructing an advocate, who gave advice leading to a decision at trial which affected the conduct of the trial, could not be sued in negligence on that account. Specifically, the majority affirmed that there were powerful reasons for the Court to refuse to re-open its decision in Giannarelli.

A factor relevant to that decision for four of the Justices (Chief Justice Gleeson and Justices Gummow, Hayne and Heydon in joint reasons) was that the Victorian Parliament had not proceeded to abolish the immunity enjoyed by barristers and solicitors, following the 1988 decision in Giannarelli. The same Justices concluded that the advocate's immunity from suit resulted from the needs of the courts to provide finality to contests and to reinforce the central principle of the judicial system that controversies, once resolved, were not to be re-opened by collateral attack, except in a very few, narrowly defined, circumstances.

The same members of the Court concluded that there were analogous instances where a wrong might occur but without a remedy, including, for example, the immunity from suit enjoyed by judges in respect of their performance of curial functions. They held that, to permit negligence suits, would be to allow a second court to impugn the final decision of an earlier court, or to permit the re-litigation of matters earlier finally determined. The also rejected an argument that a provision of the Legal Profession Practice Act 1958 (Vic) that stated that:

"Every barrister shall be liable for negligence as a barrister to the client on whose behalf he has been employed to the same extent as a solicitor was on [a date in 1881]"

cured any defects of the common law and indicated a legislative intention to establish actionable liability in barristers.

I alone dissented from all of these holdings. The result was a triumph for the principle of the immunity of the Bar in Australia, indeed, an extension of that immunity so that it would apply to solicitors as well. It applied to conduct out of court, as well as to conduct under the special pressures of incourt advocacy. Champagne corks were heard popping in Phillip Street, 
Sydney and William Street, Melbourne where many barristers are housed, on the news of the High Court's decision in March 2005.

In the argument of the D'Orta-Ekenaike case, the High Court of Australia had before it the then recent decision of the House of Lords in Arthur J S Hall \& $\operatorname{Co} v$ Simmons. ${ }^{4}$ In that appeal, the House of Lords identified a number of developments in legal practice which, they concluded, justified a reconsideration, and ultimately abolition, of the immunity for advocates from suit. The issues in the Australian case were broader and more complicated, because of the proceedings against the solicitor at the VLA, a statutory authority, and because of the history of $19^{\text {th }}$ century attempts in Victoria to amalgamate barristers and solicitors and to provide for equal liability in negligence. Still, there were common issues in the two proceedings.

The House of Lords was never formally part of the Australian judicature. Even Privy Council appeals had been terminated by the Australia Act 1986 (Aust and UK). Thus, their Lordships' decision in Arthur JS Hall did not bind the Australian courts. Nevertheless, great respect is shown throughout the Commonwealth to decisions of final national courts. A recent decision on a similar point in England was clearly the stimulus for undertaking the review of the Australian ruling in Giannarelli. It was the source of the major arguments of legal principle and policy advanced by the appellant in the Australian case. In particular, he latched on to the conclusion stated by Lord Steyn in Arthur JS Hall:

"[O]n the information now available and developments since Rondel $v$ Worsley, ${ }^{5}$ I am satisfied that in today's world that decision no longer correctly reflects public policy." 6

Whilst sweeping away the old immunity, as a relic of an exclusion from the rules applying to virtually all other professionals, some of the Law Lords in their speeches drew a distinction between collateral attacks on final judgments in civil and in criminal cases. ${ }^{7}$ Unanimously, the High Court of Australia was unconvinced that such a differentiation was conceptually viable.

In my reasons, I was required to deal with the peculiar history of the common law rule in Victoria and the foregoing special statutory provision. A dark hint in argument that the Law Lords in Arthur $J S$ Hall had been forced to come to their conclusions because of the super-imposition upon the otherwise admirable reasoning of earlier English courts of alien concepts

\footnotetext{
${ }^{4}[2002] 1$ AC 615.

5 [1969] 1 AC 191.

6 [2002] 1 AC 615 at 683.

7 [2002] 1 AC 615 at 622-625 per Lord Hope of Craighead; at 751-752 per Lord Hobhouse of Woodborough.
} 
contained in the European Convention of Human Rights. ${ }^{8}$ In fact, no mention at all had been made an argument of that instrument, a gap that I attributed to the non-application of the incorporating provisions of the Human Rights Act 1998 (UK) at the time relevant to the proceedings in the Arthur JS Hall case. Yet most of my reasons were addressed to the so-called public policy arguments deployed by the majority in the Australian decision to claim the continuance, indeed expansion, of the immunity in Australia.

Amongst other considerations, I referred to the expansion of the number of lawyers engaged in advocacy today (many of whom are not now barristers). And the conceptual difficulty of providing the immunity for supposed reasons of instantaneous judgement within court rooms, yet denying it to the decisions expected of a surgeon or of a pilot of a large passenger aircraft. ${ }^{9}$ The fact that the High Court, far from cutting back on the exceptional immunity, was pushing it into new and unhistorical applications, merely demonstrated for me the lack of convincing reasons behind the Court's proposed ruling. I am not, of course, questioning that ruling as it states the law of Australia. I am explaining why I could not join in it.

An undercurrent in the majority approach was a fear of floods of litigation, brought by discontented litigants against lawyers, which could not easily be repelled. However, I sought to respond to that fear:

"It does not happen in the United States, a most litigious country, where there has never been an immunity from suit for attorney advocates. ${ }^{10}$ It does not happen in Canada, where the courts have rejected such a general immunity. ${ }^{11}$ Instead, in that country, the courts have concentrated on developing special rules to recognise the practical problem that lawyers often face in conducting trials and giving legal advice. The general unavailability of legal aid in Australia to support negligence claims against lawyers; the availability of summary relief against vexatious claims; ${ }^{12}$ and the rules against abuse of process by re-litigation ${ }^{13}$ (not to mention the empathy and understanding of judges for co-professionals in unmeritorious cases)

${ }^{8}$ (2005) 223 CLR 1 at 99 [315].

9223 CLR 1 at 101 [322].

${ }^{10}$ Ferri v Ackerman 444 US 193 (1979). See Arthur JS Hall [2002] 1 AC 615 at 721, per Lord Hope of Craighead.

${ }^{11}$ Garrant v Moskal [1985] 2 WWR 80 at 82, applying De Marco v Ungaro (1979) 95 DLR (3d) 385; cf A Linden Canadian Tort Law ( $7^{\text {th }} \mathrm{Ed}$, 2001) p 151.

${ }^{12}$ General Steel Industries Inc v Commissioner for Railways (NSW) (1964) 112 CLR 125 at 129-130. See also Arthur JS Hall [2002] 1 ACT 615 at 691-692.

${ }^{13}$ Arthur JS Hall [2002] 1 AC 615 at 703-704 per Lord Hoffmann. 
make it completely unnecessary to retain an absolute immunity of the broad, even growing, ambit propounded in this case." 14

In these remarks, I invoked the comment of Lord Hoffmann in Arthur JS Hall:

"[The immunity] is burning down the house to roast the pig; using a broad-spectrum remedy where a more specific remedy without side effects can handle the problem equally well.,"15

To demonstrate the truth of Lord Hoffmann's dictum, I was also able to invoke the experience of litigation in Australia between the time that the trial judge had found the immunity unavailable to barristers in Victoria in Giannarelli, before that immunity was restored on appeal. There was no objective evidence of any increase in the length of criminal trials in that interval $^{16}$. Similarly, in respect of the experience of England, I had available to me a report on what had happened following the Arthur JS Hall decision. ${ }^{17}$ Only a handful of cases involving alleged negligence on the part of barristers had reportedly come to the courts. In only two of them was the barrister found liable at law. This led the commentator to conclude that the Arthur JS Hall decision:

“... does not appear to have caused any great problems for the legal profession. Indeed, the reaction of some in the profession is that it is to be welcomed, if it helps to restore public confidence in the openness and accountability of the profession." 18

To the argument of Justice Michael McHugh that the imposition of civil liability upon barristers would be "intolerable", I suggested that this could not be a governing criterion, and was not so in the case of neurosurgeons, airline pilots or others who make extremely difficult and instantaneous professional decisions but were responsible in law for fleeting acts and omissions of carelessness. ${ }^{19}$ As to the appeal to the "undeniable public interest in the

${ }^{14} 223$ CLR 1 at 103 [328].

${ }^{15}$ [2002] 1 AC 615 at 703.

${ }^{16}$ Law Reform Commission of Victoria Access to the Law: Accountability of the Legal Profession (Report No 48, 1992) pp 35-36 [78].

17 J Senevieratne "The Rise and Fall of Advocates' Immunity" (2001) Legal Studies 644 at 662 .

${ }^{18}$ Ibid, at 662, n 130.

${ }^{19}$ (2005) 233 CLR 1 at 106 [336]. 
maintenance of the independent Bar", ${ }^{20}$ I pointed out that such a Bar existed, and would continue to exist. To suggest that in Australia, uniquely, the Bar would be destroyed by removing an anomalous out of court immunity for lawyers portrayed a lack of proper confidence in the survival capacity of the highly talented advocates found at the Australian Bar. Australian barristers, and their instructing solicitors, I urged, were "made of sterner stuff." 21

To the suggestion that the reforms should be left to Parliament, I invoked Lord Steyn's conclusion in Arthur JS Hall that judges had created the immunity and judges should say that the grounds for maintaining it no longer existed. $^{22}$ The final reason for rejecting an enlargement of the immunity was that it amounted to according an anomalous, unjust and unclear exemption from legal liability to a particular class of citizens. In a modern and egalitarian society, if that were to be done, it had to be done with the express authority of Parliament. An extension of liability by judges was particularly unacceptable.

Whilst my reasons on this issue stood alone and unloved in the Australian courts, it was a tiny consolation to me to observe, soon after, that the New Zealand courts, ${ }^{23}$ in a similar challenge, preferred my approach to that of the majority of the High Court of Australia. The writing is on the wall for advocates' immunities. It is far from impossible to imagine that even the immunity of judges for instances of deliberate abuse of office or of grossly negligent decisions may need to be re-visited: not necessarily to burden the judges individually to recompense those who have suffered thereby, but to provide remedies for judicial decisions that are shown not to have been made bona fide and in the discharge of the judicial office. ${ }^{24}$

\section{OF DRUNKS}

If judges, barristers and solicitors are, on the whole, pillars of society and generally admired, or at least respected, for their learning, honesty and diligence in often stressful situations, the same qualities are not usually attributed to people who get intoxicated, and whilst intoxicated, suffer serious harm, even death.

This is particularly so in the case of injecting drug users, as witness the great difficulty experienced in societies in persuading law makers to introduce schemes of sterile needle exchange, so as to reduce the spread of HIV and

${ }^{20}$ (2055) 223 CLR 1 at 39-40 [105]-[108].

${ }^{21}$ (2005) 233 CLR 1 at 106 [338].

${ }^{22}$ [2002] 1 AC 615 at 704-705.

${ }^{23}$ Lai v Chamberlains [2006] NZSC 70; [2007] 4 LRC 79 (NZSupCt). See ibid at [50], [55], [157], [203].

${ }^{24}$ Rajski v Powell (1987) 11 NSWLR 522 (CA). 
AIDS. Despite the overwhelming evidence that such schemes radically reduce the levels of the virus in this cohort of the population, that reflects its general composition, getting sensible policies and reflecting those policies in law, is extremely difficult. ${ }^{25}$

Even with intoxication caused by alcohol (a drug that is freely available (at least to adults), generally socially accepted and heavily advertised), an antipathy creeps into legal decisions, involving tort and statute law, so as to deny rights of recovery to the intoxicated where their condition is, in part at least, the result of conduct on the part of alcohol providers. This fact was demonstrated in 2004 in a decision of the High Court of Australia on negligence liability, reached shortly before my retirement from the Court. The case was Cole $v$ South Tweed Heads Rugby League Football Club Ltd. ${ }^{26}$

On this occasion, the majority of the Court (Chief Justice Gleeson and Justices Gummow, Hayne and Callinan) concluded that, if the alcohol provider owed a duty of care, such duty had been discharged by what its employees had done in that case. Two Justices (Chief Justice Gleeson and Justice Callinan) held that the provider did not owe a general duty to take reasonable care to protect patrons against the risk of physical injury from consuming alcohol. Justice McHugh and I dissented. We concluded that there was a duty of care in the circumstances; that it had been breached; and that the breach caused the damage suffered by the plaintiff.

As is usual in cases of negligence litigation, whether involving professional negligence or otherwise, a detailed appreciation of the facts is essential to distinguish between those cases where a plaintiff succeeds and those where she fails.

Tweed Heads is a pleasant seaside holiday resort town in New South Wales, just south of the Queensland border. On a Sunday in June 1994, its rugby league football club offered a champagne (actually Spumante) breakfast free-of-charge to all comers. Mrs Cole attended and proceeded to drink large quantities of the available sparkling wine. Like other patrons, she moved from time to time between the drinking area and a vantage point where she could watch football games on the adjacent field. Her drinking continued well into the afternoon. Although by $12.30 \mathrm{pm}$, Mrs Cole was clearly intoxicated, she was still sold a bottle of wine, and was variously described as

\footnotetext{
${ }^{25}$ See the experience of the United Nations Development Programme Global Commission on HIV and the Law, of which the author is a Commissioner. The rates of HIV infection in injecting drug populations in New Zealand is $1 \%$ and in Australia $2 \%$ (where such exchange systems operate). It is $18 \%$ in Quebec and more than $30 \%$ in the United States (where such exchanges do not exist or are difficult to access). It is much higher in other countries.
}

26 [2004] HCA 29; (2004) 217 CLR 469. 
"very joyous and happy" or "an embarrassment, totally inebriated." 27 By $3.00 \mathrm{pm}$, the wife of the manager of the club refused to sell her more alcohol because of her state of insobriety. Still, she remained on the premises, and in the company of friends who, inferentially, were providing more alcohol to her.

At about $5.30 \mathrm{pm}$ in the afternoon, the club manager asked Mrs Cole to leave on account of her drunken and indecent behaviour. He offered her use of the club's courtesy bus or to call a taxi to take her home. She rejected these offers. Soon after, she left the club on foot in the company of two men, with one of whom the indecent public behaviour had occurred. At $6.20 \mathrm{pm}, \mathrm{Mrs}$ Cole suffered very serious injuries when she was run down by a motor vehicle on a public road near the club. She sued the driver of the vehicle and the club, claiming negligence.

At trial in the Supreme Court of New South Wales, the trial judge found against both defendants but concluded that there was contributory negligence on Mrs Cole's part. He apportioned liability: 30\% to each of the defendants and $40 \%$ to Mrs Cole. The New South Wales Court of Appeal upheld appeals, set aside the judgment and dismissed Mrs Cole's action. ${ }^{28}$ Special leave to appeal to the High Court of Australia was granted by Chief Justice Gleeson and me. However, the High Court, by majority, rejected the appeal.

Once again, the case was a little complicated by the intervention of statutory law. By the Registered Clubs Act 1976 (NSW), s 44A, it is an offence for a person in a registered club (like that at Tweed Heads) to supply liquor to an intoxicated person. It was not argued that this criminal provision, of itself, gave rise to a civil cause of action. But it was contended that the common law duty in negligence would mould itself to the stated parliamentary obligation. This view was rejected by a majority of the High Court in what I suggested was a "withered view of community and legal neighbourhood propounded by" them. ${ }^{29}$

In my opinion, the statutory provisions "shed light on the problems presented to the common law because they make plain the purpose of Parliament that intoxicated persons are not to be sold, or supplied with, alcohol on ... club premises." 30 Yet his had happened at $12.30 \mathrm{pm}$ when the evidence showed that Mrs Cole was already seriously affected by the free alcohol supplied to her earlier in the day. The object of the common and statutory law was to prevent things coming to the inebriated circumstances that could lead to tragic outcomes, as they often do and as they did to Mrs Cole after $6.00 \mathrm{pm}$.

\footnotetext{
27 (2004) 217 CLR 469 at 474 [6].

${ }^{28}$ Cole v Lawrence (2001) 33 MVR 159.

${ }^{29}$ (2004) 217 CLR 469 at 496 [93].

30 (2004) 217 CLR 469 at 496 [94].
} 
The majority of the High Court of Australia was understandably concerned to avoid imposing nanny-like duties on an alcohol outlet that would substitute for the freewill of the patrons, like Mrs Cole. This was obviously a proper concern. But expert evidence in the case, supported by commonsense and ordinary experience, showed the need for some firmness of action at an early, rather than later, stage in the deterioration of Mrs Cole's inhibitions and self-control. One can understand the conclusions reached by the majority. However, it was my view that a higher standard was imposed by the law for all the Mrs Coles of this world, given the role that a national final court plays in expressing the common law requirements of neighbourliness:

"The law of tort exists not only to provide remedies for injured persons where that is fair and reasonable and consonant with legal principle. It also exists to set standards in society, to regulate wholly self-interested conduct and, so far as the law of negligence is concerned, to require the individual to act carefully in relation to a person who is in law a neighbour ${ }^{31}$. The club had a commercial interest to supply alcohol to its members and their guests, including [Mrs Cole]. Doing so tended to attract them to an early-morning breakfast, to induce them to use profitable gambling facilities in the club's premises and to encourage them to use the restaurant and other outlets where alcohol would continue to be purchased or supplied to the profit of the club ... [T] he common law has long recognised that the occupier of premises owes a duty to take reasonable care for the safety of those who enter the premises. That duty arises from the occupation of premises. It extends to protection from injury from all of the activities of the premises, including, in registered premises such as the club's, the sale of alcoholic drinks." 32

Justice McHugh reached a similar conclusion. However, our opinions did not carry the day. Our references to standards that had been applied in earlier decisions in analogous cases in Australia and overseas were to no avail. Justice McHugh concluded his opinion with these words:

"No doubt some minds may instinctively recoil at the idea that the Club should be liable for injuries sustained by a drunken patron who is run down after leaving its premises. But once it is seen that the Club has a legal duty to prevent her drinking herself into a state where she was liable to suffer injury, the case wears a different complexion. The

${ }^{31}$ Donoghue v Stevenson [1932] AC 562 at 580.

32 (2004) 217 CLR 469 at 494-5 [91]. 
Club has a legal responsibility for the injury. Instinct must give way to the logic of the common law." 33

The factors that weighed on my mind were similar. According to the majority's analysis, there was no sanction upon the provider of alcohol to prevent or discourage it from plying a patron with alcohol (including free Spumante over several hours) and then taking only formal steps to provide for her return to her residence of safety. There was no reinforcement of the parliamentary will to prohibit the licensee supplying further alcohol to the intoxicated. Nothing was effectively done to diminish conduct that would reduce a decent citizen to public acts of indecency and personal gross inebriation. Truly, the law washed its hands of responsibility. It was my view that judges in a final court, at least, had to consider whether this was the standard of the law for the society they lived in. However, Mrs Cole lost her case.

A second case arose soon after my retirement from judicial office where the decision in Cole was applied in equally troubling circumstances: CAL No 14 Pty Ltd $v$ Motor Accidents Insurance Board. ${ }^{34}$ In that case, a widow instituted proceedings in the Supreme Court of Tasmania. She claimed damages as a result of the death of her husband, consequent upon injuries sustained by him when his motor cycle collided with a bridge whilst he was driving home. The claim alleged negligence on the part of the proprietor and licensee of a hotel in Triabunna, a township in beautiful Tasmania. The evidence at trial showed that the deceased arrived at the hotel at $5.00 \mathrm{pm}$. He began drinking beer and then spirits. When a rumour circulated that a police breathalyser and speed camera had been set up nearby, it was suggested to him (and he agreed) that he put the motor cycle in a locked store and collect it the next day. The licensee eventually did this and placed the keys to the motor cycle in the petty cash tin, out of reach of the deceased. This was the normal receptacle for keys handed over by customers.

The deceased then stayed on the premises for an additional hour drinking and gambling. He left the premises between $7.45 \mathrm{pm}$ and $8.15 \mathrm{pm}$. However, he soon returned demanding access to the motor cycle. The licensee offered to telephone his wife; but was rebuked: "If I want you to ring my fuckin' wife, I'd fuckin' ask you". The licensee alleged that he had asked the deceased three times whether he was fit to drive. Being assured that he was, he provided the keys to the plant room and unlocked it. The fatal accident took place at around $8.30 \mathrm{pm}$.

The trial judge (Justice Blow) rejected the claim of negligence. However, this decision was reversed by a majority of the Full Court of the Supreme

33 (2004) 217 CLR 469 at 485-6 [46].

34 [2009] HCA 49; (2009) 239 CLR 390; [2010] 1 LRC 490. 
Court of Tasmania. ${ }^{35}$ By special leave, an appeal was brought to the High Court of Australia. Justice McHugh and I having departed, that Court unanimously set aside the orders on appeal. It restored the order of the trial judge, dismissing the action. Specifically, the High Court concluded that the licensee did not owe any duties to the deceased to telephone his wife, in the circumstances disclosed, so that she could come and collect her husband. Alternatively, the majority of the judges concluded that, if there were any such duty to telephone the deceased's wife, the evidence did not support a conclusion that the accident would have been prevented by the hotelier's having done so.

To some extent, the case in Tasmania was weaker than Mrs Cole's case. The period of drinking and the degree of intoxication appears, on the evidence, to have been less prolonged and extreme. On the other hand, the significant (and certainly atypical) step by which the deceased had surrendered the keys of his motor cycle and consented to it being locked away, at least arguably, strengthened the claim of the widow. Why would this course have been suggested, still more why would it have been agreed to, if there was not already a significant and obvious problem of intoxication recognised and accepted by supplier and patron alike?

Having suggested, and agreed to, such precautions, was it a proper discharge of the duty of care to the deceased to hand over the keys and unlock the store simply because the patron demanded this course with a few ripe expletives? Was not the very act of self-deprivation in the control of the motor cycle enough to alert the licensee to the particular risk that the alcohol he was supplying can sometimes bring? This includes a diminution of the subject's self-perception and capacity of self-control by reason of the very product which the alcohol provider has a profit motive to keep supplying to the patron?

Arguably, against that potential conflict of interest and duty, the communal sense of neighbourliness, reflected in the law of negligence, requires intervention by courts to set a social standard that alcohol providers will comply with (and can themselves blame and plead in excuse) before letting loose an intoxicated patron on the public roads. Clearly, doing this involves a danger to the patron, but also to others, and to the community generally. Here, it involved a distinct danger to the patron's family who suffered the loss of a breadwinner in consequence of the turning over the keys and unlocking the store, contrary to the very precaution that the patron and licensee had earlier agreed to.

These comments do not, of course, alter the current state of the law in Australia. That law is as stated by the High Court in Cole and in CAL No 14 . But in today's world, we do not live only in our own jurisdictions. Through

${ }^{35}$ Scott v CAL No 14 Pty Ltd [No 2] (2009) 17 TasR 331. 
the internet, CommLII, AustLII, BailII and that marvellous series The Law Reports of the Commonwealth, ${ }^{36}$ all judges, and especially judges of final national courts, have daily access to contemporaneous decisions on analogous problems decided in other English-speaking Commonwealth countries.

In Canada, in 1974, in Jordan House Limited $v$ Menow, ${ }^{37}$ a patron was ejected from a hotel where he had been served with beer from the late afternoon and evening until $10.00 \mathrm{pm}$. When he was then struck by a vehicle whilst walking home and sustained serious injuries, he sued and recovered damages at trial, affirmed on appeal to the Supreme Court of Canada. Such damages were apportioned equally as between the plaintiff, the motor vehicle driver and the hotel. The Supreme Court of Canada rejected a further appeal. The Justices concluded that a duty of care existed in the circumstances; and that it was enlivened, on the evidence, by the manifest intoxication of the plaintiff.

A similar view was taken by the Supreme Court of Canada in 1995 in Stewart $v$ Pettie. ${ }^{38}$ That was a case where a passenger was seriously injured when a car, driven by her brother, crashed after the brother had been continuously served alcohol by the outlet where he had been drinking throughout the evening. The Supreme Court of Canada concluded that a duty of care existed on the part of alcohol-serving establishments towards their patrons because the latter were sometimes rendered unable to look after themselves once they become intoxicated. Furthermore, the provider owed a duty not only to the patron but also to third parties who might be dependent on his skill as a driver. Commercial vendors of alcohol were held "unquestionably" to owe a general duty of care to persons who could be expected to use the highways. Injury to a passenger of the patron was therefore foreseeable.

The Canadian court explained that the reluctance of courts to impose affirmative duties on persons for a failure to take positive action had been tempered where a "special relationship" existed between the parties that resulted in the imposition of a positive duty. The Court reached the policy conclusion that such a "special relationship" existed at the least between the vendors of alcohol and the motoring public. That duty was enlivened in the given case because nothing had been done to prevent or inhibit the driver. He was simply let loose to drive his vehicle, to the danger of his passengers, including his sister, and other members of the public. Against this danger, a higher standard of the common law of negligence applied.

\footnotetext{
${ }^{36}$ Law Reports of the Commonwealth, MD Kirby Foreword for $100^{\text {th }}$ Volume. See [2009] 2 LRC iii.

37 [1974] SCR 239 (SCC).

38 [1995] 1 SCR 131 (SCC).
} 
A review of the cases in England ${ }^{39}$ and Australia, ${ }^{40}$ before the decisions in Cole and CAL No 14 shows a large preponderance of decisions upholding claims of negligence against alcohol outlets that continued to provide their product to patrons, to the point of intoxication and beyond, where they are known to be exposed to risks on the public highway. However, in Australia, following the two recent decisions of the High Court, such authorities have been rendered dubious and it would certainly be very risky to place reliance on them. In Australia, it seems, drinking alcohol is to be left to private assessment and responsibility despite that product's inhibiting features of selfknowledge and willpower. No encouragement is to be given by the common law of negligence to self-control on the part of the outlet or customer and control by the employees. Freewill reigns.

Is this a desirable result from a social point of view? This is a question that inevitably final courts must ask themselves. Perhaps it was my early years attending Methodist churches in Sydney, and there imbibing the culture of community responsibility for its vulnerable members, that made me approach such matters with a heightened sense of the law's duty to uphold community standards and neighbourly duties.

A barrister or solicitor who can never be sued for conduct associated with advice to a client can substantially banish from his or her thinking the sanction of an unpleasant action even for egregious wrongs or the need to explain his conduct in an open court as well as to a public liability insurer. An alcohol outlet which is permitted, without legal sanction, to ply a vulnerable middle-aged woman with alcohol over six hours, or a motor cycle driver expressly recognised to need protection, over three hours, is removed from the irksome stimulus that civil liability at law can sometimes exert. Representatives of alcohol outlets then have little or no encouragement from the law to introduce rules of good practice controlling the amount of alcohol they serve to patrons over time; and the precautions (including perhaps notification to police) that they should observe, even where doing this might damage their commercial interests which are to turn a blind eye and to wash their hands of 'other peoples' problems'.

\section{OTHER PLAYERS}

\footnotetext{
39 Munro v Porthkerry Park Holiday Estates [1984] TLR 138.

${ }^{40}$ Chordas $v$ Bryant (Wellington) Pty Ltd (1988) 20 FCR 91; Johns v Cosgrove (1997) 27 MVR 110; Rosser v Vintage Nominees Pty Ltd (1998) 20 SR(WA) 78; Desmond $v$ Cullen (2001) 34 MVR 186. In all of the foregoing cases, the plaintiff succeeded.
} 
The great difficulty with the influential speech of Lord Atkin in Donoghue $v$ Stevenson ${ }^{41}$ was that it attempted to offer broad principles to guide negligence liability in a vast range of factual circumstances, in the place of the earlier categorisations of causes of action by reference to factual peculiarities. Every judge and every law student knows the famous passage I refer to. It may be Delphic and even circular, as its critics suggest. But it is seeking to express a broad principle based, ultimately, on notions of community ethics:

"[I]n English law there must be and is some general conception of relations giving rise to a duty of care, of which the particular cases found in the books are but instances. The liability for negligence, whether you style it as such or treat it as in other systems as a species of "culpa", is no doubt based upon a general public sentiment of moral wrongdoing for which the offender must pay. But acts or omissions which any moral code would censure cannot in a practical world be treated so as to give a right to every person injured by them to demand relief. In this way, rules of law arise which limit the range of complainants and the extent of their remedy. The rule that you are to love your neighbour becomes in law: You must not injure your neighbour, and the lawyer's questions: Who is my neighbour? receives a restricted reply. You must take reasonable care to avoid acts or omissions which you can reasonable foresee would be likely to injure your neighbour. Who then, in law, is my neighbour? The answer seems to be persons who are so closely and directly affected by my act that I ought reasonably to have had them in contemplation as being so affected when I am directing my mind to the acts or omissions which are called in question." ${ }^{42}$

At the very end of his speech, Lord Atkin went on to say, in words that are rarely quoted:

"[This] is a proposition that I venture to say no-one in Scotland or England who is not a lawyer would for one moment doubt. It will be an advantage to make it clear that the law in this matter, as in most others, is in accordance with sound commonsense." ${ }^{43}$

So if the facts are overwhelmingly influential in the outcome of cases of negligence at common law, and if the scope of liability depends on a kind of moral equation, the obvious need in society is to cut the Gordian knot that is

\footnotetext{
41 [1932] AC 562.

42 [1932] AC 562 at 580.

43 [1932] AC 562 at 586.
} 
presented by Lord Atkin's notion of close and direct affectation that reasonably engages the mind of those whose acts and omissions can otherwise cause harm to others, because they are closely and directly affected by the decisions that need to be made.

In Australia, for some time, a test of "legal proximity" was adopted to control the finding of whether a duty of care in law should be upheld or denied $^{44}$. By the time I was appointed to the High Court of Australia, this theory of "proximity", although still "in use", was undergoing critical reappraisal, in England, Australia and elsewhere. In England, Lord Oliver had thrown cold water on the notion in Caparo PLC $v$ Dickman. ${ }^{45}$ In Australia, this fact eventually encouraged its abandonment in Sullivan $v$ Moody. ${ }^{46}$ This was because a majority of the High Court of Australia had, by that stage, been assembled which considered that "proximity" was too openended; that the imperial march of negligence had to be reversed; that costs of insurance were becoming excessive; and that plaintiffs' claims needed to be contained and rejected.

In a series of decisions in the High Court of Australia, ${ }^{47}$ seeing the writing on the wall of these developments, I urged that the way to tame the tort of negligence - and to control its suggested excesses - was to adopt the threestage test for finding a duty of care expressed by Lord Bridge of Harwich in Caparo. ${ }^{48}$ This, in turn, was somewhat similar to an incremental approach earlier suggested by Justice Brennan in the High Court of Australia. It requires examination of:

(1)Whether it was reasonably foreseeable to the alleged tortfeaser that the particular conduct or omission would be likely to cause harm to a person such as the claimant;

(2)Whether between that tortfeaser and the claimant, a relationship existed that would be characterised as one of proximity or neighbourhood; and

\footnotetext{
44 See eg Jaensch v Coffey (1984) 155 CLR 549.

45 [1990) 2 AC 605 at 633. Cf D Mendelson "Torts" (Chapter 32) in Appealing, above $\mathrm{n} 2$, at 821 .

46 (2001) 207 CLR 562.

47 Pyrenees Shire Council v Day (1998) 192 CLR 330 at 420-427 [246]-[253]; Romeo v Conservation Commission (NT) (1998) 192 CLR 431 at 476-477 [117]-[121], 484485 [138]-[140]; Perre v Apand Pty Ltd (1999) 198 CLR 180 at 286-291 [289]-[302]; Crimmins v Stevedoring Industry Finance Committee (1999) 200 CLR 1 at 80-86 [223]-[235; Brodie v Singleton Shire Council (2001) 206 CLR 512 at 604-5 [241].

48 [1990] AC 605 at 617-618.
} 
(3)If so, whether it was fair, just and reasonable that the law should impose a duty of a given scope upon that tortfeaser for the benefit of that person? ${ }^{49}$

At the least, I hoped that this approach would provide a control over idiosyncratic narrowing of liability in negligence and oblige judges (especially in the final court) to address candidly the issues of public policy enlivened in every case by the third question. Thus, in the cases I have examined, the public policy of imposing (or exempting from) liability for the provision of legal advice by advocates (alone of all professionals) and the public policy of effectively exempting alcohol providers from accepting and safeguarding patrons (some of whom will be extremely vulnerable) from the very consequences that the provision of alcohol for profit will occasionally cause is central.

My quest ultimately came to nothing. It was finally rejected in Australia in Sullivan v Moody. ${ }^{50}$ As more and more plaintiffs failed in proceedings in the High Court of Australia, I called attention to the pulling up of the drawbridge from the tradition of community responsibility and neighbourliness. And the substitution of a "shift of legal policy, albeit one that is not usually spelt out and justified by judges as the Caparo approach would require."

In the place of "proximity", or the Caparo enquiry into fairness, justice and reasonableness, the Australian law appears to have embraced a broad touchstone of "reasonableness" in determining when a duty of care will be imposed. ${ }^{51}$ In my last years in the High Court, I accepted the duty "for the time being" to conform to the majority opinion. ${ }^{52}$ However, I confessed that I did so with without enthusiasm or a conviction that a generalised search amongst the "salient features" of the facts of each case was a sensible substitute for a more principled, conceptual and candid approach to charting the metes and bounds of negligence liability.

In coming to this conclusion, I was influenced not so much by the Methodists of my youth as by my service in my middle years in institutional law reform. There, as Lord Scarman had taught, the role of lawyers was, at least partly, to forsake the pragmatic problem-solving, minimalist approaches of the common law - stumbling from one decision to the next. Instead, it was to try to perceive each new problem in the context of the broad canvas of the law. And always to ask how the answer to the particular case would advance

\footnotetext{
${ }^{49}$ Citing Graham Barclay Oysters Pty Ltd v Ryan (2002) 211 CLR 540 at 623 [232].

${ }^{50}$ (2001) 207 CLR 562 at 579 [49]-[53].

${ }^{51}$ Neindorf v Junkovic (2005) 80 ALJR 341 at 356-347 [30]; (2006) 2 LRC 629, AusHC.

${ }^{52}$ Graham Barclay Oysters (2002) 211 CLR 540 at 626 [238].
} 
desirable outcomes, not only for the parties, but for the community generally that must live with the judicial resolution of the parties' litigious conflict.

All of which is to say little more than what that earlier judicial conceptualist, Lord Atkin, had remarked in Donoghue $v$ Stevenson. That each particular case must always be seen in our law as an instance of a broader genus. That judges of final courts have an extra duty to search for, and express, the broader principles that should guide later and lower courts and ordinary citizens and their lawyers, as surely as statutes do. And that, in the end, they should test their conclusions by the intuitive responses about the content of law that would be held by non-lawyer citizens applying sound commonsense to legal outcomes. ${ }^{53}$

If this approach is followed in the two instances I have studied by reference to plain tales from Australia, I do not myself doubt the outcome that should be adopted. Exceptional immunities from liability in negligence would be denied to, still less expanded for, lawyer advocates and their solicitors. And effective immunity would equally be denied to alcohol outlets sheltering behind notions of freewill as they sell their product that has the inevitable effect of diminishing the very willpower in the consumers said to justify self responsibility. The outcomes of each case would necessarily depend on the facts and circumstances accepted at trial. The removal of accountability in negligence is intuitively wrong. It is contrary to the neighbourhood principle as Lord Atkin expounded it.

To the extent that the law concludes otherwise, it needs re-examination. And in the cyclical way of these things, such re-examination will one day come. Lord Taylor's life journeyed marvellously on the cycle and he rose to become the Lord Chief Justice of England and Wales. Too soon, he died. Those who are still on the journey have the responsibility to search for principle and justice; and to make sure, if possible, that these two great forces of the law coincide.

${ }^{53}$ See Travel Compensation Fund v Tambree (2005) 224 CLR 627 at 648 [64]. 